\title{
The Influence of Social Relationships on Conduct Problems in School Context - Does School Engagement Matter?
}

\author{
Alexander Lätsch*, Diana Raufelder ${ }^{*}$ and Tino Wulff
}

\author{
University of Greifswald, Germany
}

\begin{abstract}
There has been an increase in the prevalence of problem behavior during adolescence over the last decades. Thereby, studies have found that social bonds and relationships as well as school engagement as a form of connectedness play an important protective role. However, less is know whether school engagement is as a potential mediator in the association of social relationships with peers and teachers and conduct problems. The current study examined this interplay in a large non-clinical sample of students $\left(N=1.088 ; M_{\mathrm{Age}}=13.7 \mathrm{SD}=0.53\right.$ at T1; $N=845 ; M_{\mathrm{age}}=$ $15.32, S D=.49$ at T2) in secondary schools in Brandenburg, Germany. Structural Equation Modeling (SEM) was used to test the mediating effect from school engagement in the association between students' social relationships in early adolescence and conduct problems in middle adolescence. The results show that school engagement function as full mediator in the association of both student-student relationships and teacher-student relationships at T1 and conduct problems at T2. This highlights that fostering school engagement in early adolescence might be an essential starting point for prevention and intervention strategies of conduct problems in middle adolescence.
\end{abstract}

Keywords: Social relationships, school engagement, conduct problems, adolescence.

\section{INTRODUCTION}

There has been an increase in the prevalence of problem behavior during adolescence over the last decades, which has also been a national concern since then (Dryfoos 1990; Feldman and Elliot 1990; SimonsMorton et al. 1999). This is dramatic, because problem behavior is associated with essential negative health and social outcomes such as school failure, school dropout, sexual transmitted diseases, pregnancy early in live, injury and death (Dryfoos 1990; Feldmann and Elliott 1990; Jessor and Jessor 1977; Simsons-Morton et al. 1999). One form of problem behavior is conduct problems, manifested in cheating behavior, anger, temper and disobedience (Goodman 1997), which can often lead to delinquency years later (Loeber 1988; Loeber and Dishion 1983).

It is known that conduct problems and delinquency are negatively linked to social bonds in school context (Cernkovich and Giordano 1992; Liska and Reed 1985) such as teachers and peers, which stands for the way and strength in which students are connected to and invested in their schools (Cernkovich and Giordano 1979; Hierschfield and Gasper 2011; Hirschi 1969; Liska and Reed 1985). Students who perceive positive social relationships in school show less aggressive behavior, antisocial behavior, delinquency and conduct problems (Bear et al. 2014; Brand et al. 2003; Bru et al. 2002; Hamre et al. 2008; Meehan et al. 2003; Resnick et al. 1997) like bullying (Bear et al. 2014; Gregory et

*Address correspondence to these authors at the University of Greifswald, Germany; Tel: +49-(0)3834-863710; Fax: +49-(0)3834-863702; E-mail: diana.raufelder@uni-greifswald.de, alexander.laetsch@uni-greifswald.de

E-ISSN: $1929-4409 / 16$ al. 2010). In addition, there is a positive relation between positive social relationships and academic initiative or engagement (Bear et al. 2014; Danielsen et al. 2010; Hughes et al. 2008). The latter can be understood as another form of bonding to school preventing problem behavior (Hawkins et al. 1992; Murray and Greenberg 2001; Werner and Smith 1989). In contrast, studies have shown that students who are less engaged, perform poorly in school, and feel alienated from school are more likely to show delinquency and school dropout (Hierschfield and Gasper 2011; Simons-Morton et al. 1999). Students who develop a positive affiliation or bond to peers, teachers or school are more likely to remain academically engaged and are less likely to engage in conduct problems and other antisocial behavior (Hierschfield and Gasper 2011; Simons-Morton et al. 1999). One social control theory in criminology includes social relations and deviant behavior in one concept the social bond theory of Hirschi (1969). Following Hirschi (1969), social relationships and bonds (attachment, commitment, involvement and belief) should prevent an individual to act deviant or delinquent. Based on this theory, the component of attachment manifested in positive social relationships with peers and teachers might be essential for students to feel engaged in school and to prevent conduct problems as a potential pre-stage of delinquent behavior (Loeber 1988; Loeber and Dishion 1983). However, less is known whether behavioral and/or emotional school engagement function as mediators between social relationships with teachers and peers in early adolescence and conduct problems in middle adolescents. 


\section{Social Bonds and Conduct Problems}

Following Hirschi (1969), social relationships and bonds should prevent an individual to act deviant or delinquent. In this theory there are four concepts that act preventively: attachment, commitment, involvement and belief. Attachment defines the sensibility of an individual towards others' attitude (Eifler 2002; Hirschi 1969). A student which is highly attached to others wants them to think positive of themselves. In other words, if a student has a strong attachment to his or her social environment in which deviant behavior is defined negatively, this student won't act deviant to prevent that other think negative. Commitment describes the extend to which individuals have invested in conventional goals. The idea is that individuals which have invested a lot in conventional goals have a lower possibility to act deviant because they don't want to compromise their goals (Eifler 2002; Hirschi 1969). The concept of investment describes the amount to which an individual is temporally bonded to conventional activities. The idea of investment is, that individuals which spends a huge amount of time in conventional activities do not have time to involve in deviant behavior and acts (Eifler 2002; Hirschi 1969). Last but not least belief defines the belief of individuals in the legitimate system of norms and values of a society. If an individual has a strong belief in this system, the possibility that this individual break those will decrease (Eifler 2002; Hirschi 1969). According to social bond theory, Loukas and colleagues (2009) found that low connectedness to school including poor relationships with peers and teachers predicted high self-reports of conduct problems in the second wave - significant for males and females. Hughes, Cavell and Jackson (1999) have found in a longitudinal study that the quality of teacher-student-relationship predicts students' conduct problems in late childhood. Besides attachment with teachers and peers, school engagement can be understood as social bond as well, implying investment, commitment and belief (Hirschi 1969).

\section{The Role of School Engagement}

Most research on school engagement distinguish between a behavioral, emotional and cognitive dimension (Fredricks et al., 2004; Upadyaya and Salmela-Aro 2013). Whereas constructs focusing on cognitive engagement are quite similar to those in research on motivation, emotional school engagement refers to students' feelings towards social (e.g., teachers, classmates) and institutional bonds (e.g., school values and rules), and behavioral school engagement describes students' involvement in school activities and participation in the classroom (Fredricks et al. 2004) including commitment, investment and belief (Hirschi 1969). Both emotional and behavioral school engagement have been found to reduce school dropout rates (Fall and Roberts 2012; Fredricks, Blumenfeld, and Paris 2004) and predict high academic achievement for various demographics (e.g. gender, race, ethnicity and socio-economic status) (Estell and Perdue 2013; Finn and Rock 1997). In addition, a study by Hirschfield and Gasper (2011) has shown that emotional and behavioral school engagement causes decreases in school and general delinquency. In detail, emotional engagement as a form of belief reduces school misconduct to the extent that it helps youth forge strong emotional connections with school actors, especially teachers and similarly engaged peers (Steinberg and Avenevoli 1998). In line with social bond theory (Hirschi 1969), behavioral school engagement as a form of commitment, investment and belief reduces the time, energy and will of students to involve in conduct problems and other deviant actions. Furthermore, both the quality of teacher-student relationship and student-student relationship have significant impact on school engagement (see Fredericks et al. 2004; Perdue, Manzeske and Estell 2009; Roorda, Koomen, Spilt, and Oort 2011). However, until today there is no research examining school engagement as a potential mediator in the association of social relationships with peers and teachers and conduct problems.

\section{Current Study and Hypotheses}

The aim of this study is to fill this gap by examine whether teacher-student relationship and studentstudent relationship in early adolescence influences conduct problems in middle adolescence in a nonclinical sample. Moreover, it will be examined whether this relationship is mediated by emotional and/or behavioral school engagement. Following the modus operandi suggested by Baron and Kenney (1986) - we met all preconditions of a mediation analysis: as shown in the introduction, the predictor variables (teacherstudent relationship and student-student relationship) are significantly related to the outcome variable (conduct problems), and the mediating variable (school engagement) is significantly related to both the outcome variable and the predictor variable. Based on 
the above mentioned theoretical and empirical research approaches, it was hypothesized that (1) emotional school engagement would mediate the associations between teacher-student relationship and student-student relationship and conduct problems. Furthermore, we hypnotized that (2) behavioral school engagement would mediate the associations between teacher-student relationship and student-student relationship and conduct problems.

\section{METHOD}

\section{Participants and Procedure}

Quantitative questionnaire survey data of 1088 students from 23 public secondary schools - randomly selected out of a pool of 124 secondary schools located in the federal state Brandenburg, Germany build the empirical base of the present study. Five of the participating schools were in the biggest cities of Brandenburg (i.e. Potsdam, Cottbus, Frankfurt Oder, Brandenburg, and Prenzlau) and 18 of the participating schools were in rural areas in order to provide a representative sample. The data were collected in summer and autumn term 2011 (T1) and in spring term 2013 (T2). Initially, the 1088 students were in $8^{\text {th }}$ grade $\left(M_{\mathrm{age}}=13.70, S D=0.53, \mathrm{~T} 1\right)$. On T2 the 845 students (22.33\% retention rate; sex and age at the first occasion of measurement were no predictors of dropout) were in $9^{\text {th }}$ grade $\left(M_{\text {age }}=15.32, S D=.49\right)$. This study is focused on this particular age group due to the rapid decline observed in early adolescent students' motivation, following the transition to secondary school and continuing throughout the first three years of high school (Harter 1996), reaching its nadir in grade nine (Eccles, Wigfield, and Schiefele 1998; Watt 2004; Pintrich and Zusho 2001).

All procedures were in accordance with the ethical standards of the Helsinki Declaration of 1975, revised in 2000 and 2008. Permission to conduct the study was obtained from the Department of Education, Youth and Sports of Brandenburg, as well as from participating parents and students. Schools, parents and students were thoroughly informed about the voluntary nature of their participation, including confidentiality and their right to refuse any answers or withdraw from the study at any time. Data collection occurred in classrooms, which too approximately 2 hours per classroom. In each session, at least two members of the research team were present to clarify any uncertainties relating to items or questions. Students completed the questionnaires by paper and pen.

\section{Measures}

The following measures used in this study are wellestablished, validated self-report instruments for German adolescent students. The reported reliability values are based on the current sample.

The quality of the Student-Student Relationship (SSR) was measured with the scale from the Program for International Student Assessment (PISA) (Kunter et al. 2002), containing six statements such as "In class, everyone only looks out for themselves when it comes to getting good grades" and "You easily become an outsider when you are not doing what the class presumes as right" on a 4-point Likert scale from 1 (strongly disagree) to 4 (strongly agree). All negative items were recoded for the current analyses. The instrument showed an internal reliability of Cronbach's $\alpha=.70$.

The quality of the Teacher-Student Relationship (TSR) was also measured with an instrument from the PISA (Kunter et al. 2002), containing five statements such as "Most of the teachers treat me fairly" and "When I need additional help, I get it from my teachers", which students should rate on a 4-point Likert scale from 1 (strongly disagree) to 4 (strongly agree). This scale has an internal reliability of $\alpha=.78$.

Conduct Problems was measured with a subscale of the strength and difficulties questionnaire (SDQ) developed by Goodman (1997). Students described how well the statements of the four items describe their feelings and behavior on a 3-point scale from 1 (do not agree) to 3 (totally agree). The subscale consists statements such as "I get angry and often lose my temper"; "I usually do as I am told"; "I fight a lot"; "I am often accused of lying or cheating" (Goodman, 1997). Cronbach's alpha reliability coefficient was .61 at T2. However, Kopp and Lois (2012) argue that the critical value of Chronbach's is $\alpha>.50$, so that parceling is possible.

School Engagement was measured with a twocomponent model based on the work of Skinner, Kindermann, and Furrer (2009), featuring a behavioral (e.g. positive conduct, effort and participation) and an emotional (e.g. interest, identification, belonging and positive attitude about learning) component (Finn 1993; Marks 2000; Newmann, Wehlage, and Lamborn 1992; Willms 2003). Both the emotional school engagement (ESE) scale (e.g., 'Class is fun') and the behavioral school engagement (BSE) scale (e.g., 'In class I work 
as hard as I can') contained a 6 -item scale ( $\alpha=.70$ and $\alpha=.74$, respectively). Items were presented as statements and participants answered how well each statement described their feelings or behavior on a 5point Likert scale that ranged from 1 (strongly disagree) to 5 (strongly agree).

\section{Statistical Analyses}

To test our hypotheses, we conducted Structural Equation Modeling (SEM) with mediation analyses in two models. Model A included four latent constructs (TSR at T1, SSR at T1, ESE at T1, conduct problems at T2), as well as Model B included four latent constructs (TSR at T1, SSR at T1, BSE at T1, conduct problems at T2). Model A contained direct effects from TSR and SSR on ESE and conduct problems, as well as from ESE to conduct problems. In addition, indirect effects from TSR and SSR on conduct problems through ESE were included. Model B contained direct effects from TSR and SSR on BSE and conduct problems, as well as from ESE to conduct problems. In addition, indirect effects from TSR and SSR on conduct problems through BSE were included. To assess these indirect effects (mediation) confidence intervals around the estimates (Christ and Schlüter 2012; MacKinnon 2008; Preacher and Hayes 2008) has been constructed. This procedure reduces bias caused by the non-normality in the sampling distribution of indirect effects (Shrout and Bolger 2002).

All analyses were conducted with the statistics software Mplus, version 7.0 (Muthén and Muthén 19982010) and maximum likelihood estimation (MLR) with robust standard errors and chi-square values. To evaluate the goodness of fit of the models the following criteria were employed: Yuan-Bentler scaled $x^{2}$, Tucker and Lewis index (TLI), comparative fit index (CFI), root mean square error of approximation (RMSEA) with associated confidence intervals, and standardized root mean square residual (SRMR). The multilevel approach TYPE is COMPLEX in the Mplus syntax was used to correct standard errors and chi-square values for the nested structure of the data (T1: 1088 students in 72 school classes; T2: 845 students in 67 school classes) (MacKinnon 2008). This multilevel approach corrects for standard error biases created by the nested nature of the data (Asparouhov 2005). To account for missing data the models were estimated with full information maximum likelihood (FIML). Hence, after carefully considering the advantages and disadvantages of parceling compared to single item based solutions, parcels based on the used items were randomly built. This decision was made due to the present orientation towards using parcels applying Structural Equation Modeling (for a review see Bandalos and Finney 2001), although it has been controversially discussed (Marsh, Lüdtke, Nagengast, Morin, and Von Davier 2013), as it may disguise misspecification with item parcels in confirmatory factor analysis models. Nevertheless, the application of parcels has been shown to result in better fitting solutions and less bias in estimates of structural parameters in comparison to item based solutions (Bandalos 2002; Little, Cunningham, Shahar, and Widaman 2002; Nasser and Wisenbaker 2003). Little, Cunningham, Shahar and Widaman (2002) list various reasons, why working with parcels can be advantageous, such as: (1) spurious correlations may be a result of estimating large numbers of items, (2) specific sources of variance that may not be from primary interest may be shared by a subset of items from a large item pool, (3) stable solutions are less likely to be a result of item-level data. Hence, by applying the technique of parceling, the original large number of items is being reduced, yielding stable solutions by preventing potential spurious correlations and variance sharing. Additionally, in their simulation study, Nasser and Wisenbaker (2003) advise using parcels over item solutions, if the sample size exceeds 100 , which is the case in the current study. Subsequently, to test the hypotheses, parcels were built randomly from the items of SSR, TSR, BSE, ESE and conduct problems variables. Building parcels randomly is a common technique in psychological research (Marsh, Hau, Balla, and Grayson 1998; Nasser and Wisenbaker 2003; Prats 1990). Subsequently, all items of the measures were transformed randomly into two parcels each. Hence, the six items of SSR and the five TSR items were transformed into two parcels consisting of three and three items (SSR) and two and three items each (TSRT1P1, TSRT1P2, SSRT1P1, SSRT1P2), whereas the four items of the conduct problems subscale were transformed into two parcels consisting of two items each (Conduct Problem Scale: CPT2P1, CPT2P2).

\section{RESULTS}

\section{Descriptive Statistics and Intercorrelations}

Table 1 presents descriptive statistics (range, means, standard deviation, skewness and curtosis) and intercorrelations between the variables of interest. Following West, Finch, and Curran (1995) that skewness values below 2 and kurtosis values below 7 
Table 1: Intercorrelations between Variables of Interest, Mean, Standard Deviation (SD), Range, Skewness and Kurtosis

\begin{tabular}{|c|c|c|c|c|c|c|c|c|c|}
\hline & $\mathbf{1}$ & $\mathbf{2}$ & $\mathbf{3}$ & $\mathbf{4}$ & Mean & SD & Range & Skewness (SD) & Kurtosis (SD) \\
\hline \hline 1. BSE T1 & -- & & & & 2.79 & .02 & $1-4$ & $-.12(.08)$ & $-.07(.15)$ \\
\hline 2. ESE T1 & $.66^{* *}$ & -- & & & 2.74 & .01 & $1-4$ & $-.37(.08)$ & $.74(.15)$ \\
\hline 3. TSR T1 & $.43^{* *}$ & $.53^{* *}$ & -- & & 2.85 & .02 & $1-4$ & $-.27(.08)$ & $.74(.15)$ \\
\hline 4. SSR T1 & $.18^{* *}$ & $.23^{* *}$ & $.19^{* *}$ & -- & 2.65 & .02 & $1-4$ & $-.23(.08)$ & $.18(.15)$ \\
\hline 5. CP T2 & $-.25^{* *}$ & $-.22^{* *}$ & $-17^{* *}$ & $-.13^{* *}$ & 1.35 & .01 & $1-3$ & $1.35(.09)$ & $1.84(.17)$ \\
\hline
\end{tabular}

Note. All measures are standardized. ${ }^{*} p<.05 ;{ }^{* *} p<.001$.

$\mathrm{SSR}=$ Student-Student-Relationship, TSR $=$ Teacher Student Relationship, ESE $=$ Emotional School Engagement, $\mathrm{BSE}=$ Behavioral School Engagement, $\mathrm{CP}=$ Conduct Problems.

signify a normal distribution the variables of this study can be handle as normal distributed.

The intercorrelation matrix shows positive associations between BSE and TSR $(r=.43, p<.001)$ and SSR $(r=.18, p<.001)$, as well as between ESE and TSR $(r=.53, p<.001)$ and SSR $(r=.23, p<.001)$. Furthermore, high levels of conduct problems at T2 were associated with low levels of $\operatorname{BSE}(=-.25, p<$ $.001)$, ESE $(r=-.22, p<.001)$, TSR $(r=-.17, p<.001)$ and SSR at T1 $(r=-.13, p<.001)$. All correlations were significant and supported our initial hypotheses.

\section{Structural Equation Modeling (SEM)}

We constructed two Structural Equation Models: Model A included direct paths from perceived TSR and SSR on ESE and conduct problems, as well as from ESE to conduct problems. Furthermore, indirect effects from TSR and SSR on conduct problems through ESE were contained. Model B involves direct effects from TSR and SSR on BSE and conduct problems, as well as from BSE to conduct problems. Besides, indirect effects from TSR and SSR on conduct problems through BSE were included.

\section{Model A (Proposed Mediator: ESE)}

The analysis showed a good model fit: $\left(X^{2}(14)=\right.$ 46.32, $p<.001$; CFI $=.98$, RMSEA $=.05$; SRMR $=.03$ ).

\section{Direct Effects}

The associations between TSR and ESE $(B=0.56$, $\beta=0.72, S E=0.05, p<.001)$ and SSR and ESE $(B=$ $0.14, \beta=0.17, S E=0.04, p<0.05$ ) were found to be significant. In addition, the direct effect of ESE on conduct problems $(B=-0.35, \beta=-0.53, S E=0.10, p<$ $.001)$ was highly significant. In contrast, the direct effects of TSR on conduct problems $(B=0.06, \beta=$ $0.12, S E=0.06, p>.05)$ and SSR on conduct problems $(B=-0.02, \beta=-0.04, S E=0.04, p>.05)$ were not significant.

\section{Indirect Effects}

Both indirect effects of TSR $(B=-0.19, \beta=-0.38$, $S E=0.06,95 \% \mathrm{Cl}[-0.30,-0.10])$ and SSR $(B=-0.05$, $\beta=-0.09, S E=0.02,95 \% \mathrm{Cl}[-0.09,-0.01])$ on conduct problems fully mediated by ESE were found to be significant. Overall, the combined effects for this mediation model explained about $21 \%$ of the variance of conduct problems $\left(R^{2}=0.21\right)$.

\section{Model B (Proposed Mediator: BSE)}

SEM revealed a good model fit: $X^{2}(14)=26.14, p<$ $.001 ; \mathrm{CFI}=.99, \mathrm{RMSEA}=.03 ; \mathrm{SRMR}=.02$ ).

\section{Direct Effects}

The association between TSR and BSE ( $B=0.47, \beta$ $=0.57, S E=0.05, p<.001)$ was found to be significant, whereas the path between SSR and BSE ( $B$ $=0.06, \beta=0.06, S E=0.05, p>.05$ ) was not significant. However, the direct effect of BSE on conduct problems $(B=-0.29, \beta=-0.46, S E=0.06, p<$ $.001)$ was significant. In contrast, the associations between conduct problems and both TSR $(B=0.00, \beta$ $=-0.01, S E=0.03, p>.05)$ and SSR $(B=-0.05, \beta=-$ $0.08, S E=0.03, p>.05$ ) were not significant.

\section{Indirect Effects}

Supporting our hypotheses, we found a significant indirect effect of TSR on conduct problems fully mediated by BSE $(B=-0.14, \beta=-0.26, S E=0.03$, $95 \% \mathrm{Cl}[-0.19,-0.09]$. In contrast and against our hypotheses, SSR and conduct problems were not mediated by BSE $(B=-0.02, \beta=-0.03, S E=0.02$, $95 \% \mathrm{Cl}[-0.05,0.01])$. Overall, the combined effects for this mediation model explained about $24 \%$ of the variance of conduct problems $\left(R^{2}=0.24\right)$. 


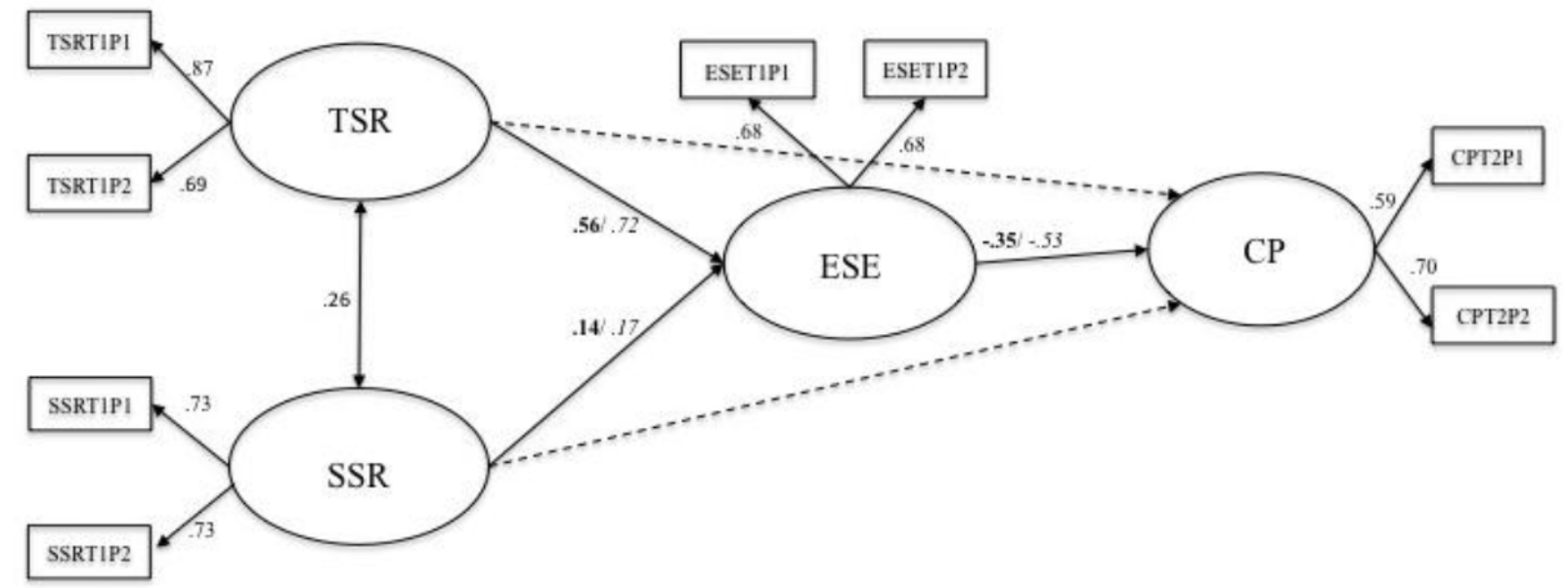

Figure 1: Structural Equation Modeling (SEM) Model A: Interplay of Teacher-Student-Relationship (TSR), Students-StudentRelationship (SSR) and Conduct Problems (CP), mediated by Emotional School Engagement (ESE). T1= Time 1 and T2= Time 2 (1.5 years later); P1 = Parcel 1; P2 = Parcel 2. Significant effects shown as unstandardized coefficients (B) in bold face and standardized coefficients $(\beta)$ in italics; bold pathways are significant at $p<.001$; dotted pathways are not significant; factor loadings are standardized.

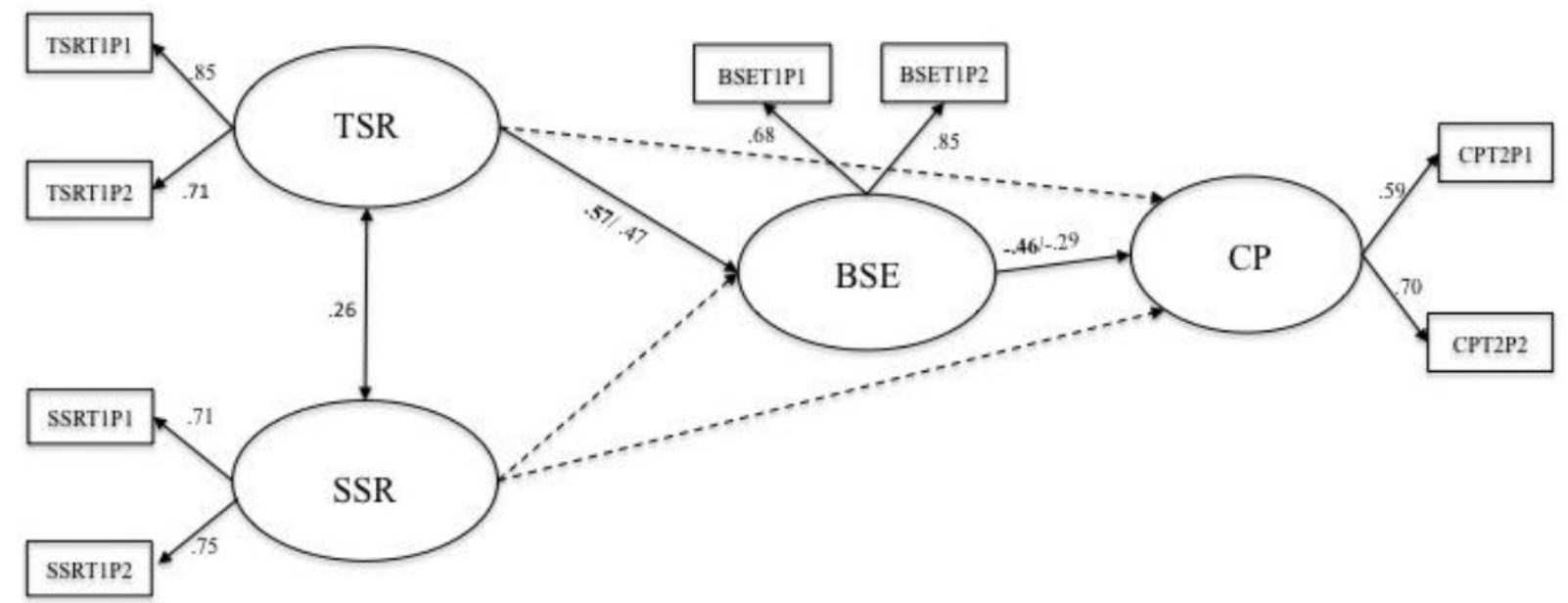

Figure 2: Structural Equation Modeling (SEM) Model B: Interplay of Teacher-Student-Relationship (TSR), Students-StudentRelationship (SSR) and Conduct Problems (CP), mediated by Behavioral School Engagement (BSE). T1= first measurement point; $\mathrm{T} 2=$ second measurement point $(1.5$ years later); $\mathrm{P} 1=$ Parcel $1 ; \mathrm{P} 2=$ Parcel 2 . Significant effects shown as unstandardized coefficients (B) in bold face and standardized coefficients $(\beta)$ in italics; bold pathways are significant at $p<.001$; dotted pathways are not significant; factor loadings are standardized.

\section{DISCUSSION}

Based on social bond theory, the present study examined the mediating role of school engagement in the association between students' social relationships in early adolescence and conduct problems in middle adolescence.

In line with our first hypothesis, it was found that ESE fully mediated the association between TSR, SSR and conduct problems. Put simply, ESE drops the effects between TSR and SSR and conduct problems to zero. Students who are emotionally engaged at schools in early adolescence showed less conduct problems in middle adolescence. Therefore, high ESE can be seen as an important preventive factor of conduct problems. This highlights the importance of emotional bonding to teachers and peers (emotional attachment) and school (belief in school system and values and norms of school) and therefore ESE enhanced by social relationships with teachers and peers, as the direct paths in SEM have shown. This finding stands in line with the result found by Estell and Perdue (2013) and Perdue, Manzeske and Estell (2009) that peer support and friendship are positive associated with ESE. Furthermore, this result stands in line with studies, which have shown that bonding to school manifested in (emotional) engagement function as a preventive factor of problem behavior and conduct 
problems (Hawkins et al. 1992; Murray and Greenberg 2001; Werner and Smith 1989). In accordance with the findings of Steinberg and Avenevoli (1998), the results of this study showed that emotional engagement as a form of institutional bond (according to Hirschi's (1969) bond theory manifested in attachment and belief) function as a protective factor of school misconduct.

In line with the second hypothesis, it was found that BSE fully mediated the association between TSR and conduct problems. In other words, BSE drops the relationship between TSR and conduct problems to zero. That means that students with poor social relationship to teachers in early adolescence can be prevented to show conduct problems in middle adolescence through high levels of BSE. As the direct path in the SEM has shown, positive relationships with teachers are positively associated with BSE. This finding supports social bond theory (Hirschi 1969), such as commitment, investment and belief manifested in BSE function as protective factors of delinquent behavior, such as conduct problems. In contrast, the path between SSR and BSE was not significant. This result also stands in line with Estell and Perdue (2013), which have shown that peer support has no influence on BSE but ESE. In other words, the current findings provide evidence that students' relationships with teachers are tend to play a more essential role for BSE than relationships with peers.

In contrast to the second hypothesis, BSE does not function as mediator in the association between SSR and conduct problems, as there is no significant direct effect between SSR and conduct problems. This might be due to the fact that peers might have more influence on "stronger" external-motivated deviant or delinquent behavior instead of fostering anger manifested in internal-motivated conduct problems. Future studies are warranted to further examine the role of students' relationship with peers and teachers by differentiating external-motivated (e.g., delinquency) and internalmotivated (e.g., conduct problems) problem behaviors.

Overall, our results extend the findings from Hirschfield and Gasper (2011), showing that both BSE and ESE in early adolescence not only decrease delinquency, but also conduct problems in middle adolescence. In sum, it may be important to create a participative and trustful environment by fostering students' BSE and ESE, which help to prevent early adolescent students to engage in problem behavior in middle adolescence.

\section{LIMITATIONS, STRENGTH AND FUTURE RESEARCH}

When interpreting the current results, some limitations should be considered. First, the results were obtained to German adolescents. Therefore, replication studies with students from other countries and ethnical backgrounds are warranted to allow a generalization of these findings. Furthermore, future studies should examine potential gender differences as research has shown that boys tend to report higher problem behaviors than girls (Caprara et al. 2014; Costello et al. 2006; Petermann and Petermann 2013). Second, measuring conduct problems in the present study might be limited due to the fact that the items are manly focused on internal-motivated (e.g., anger, disobedience) problem behavior. Therefore, future studies should use additional instruments including external-peer- motivated problem behaviors. Furthermore, different forms (e.g., conduct problems, deviant behavior, delinquency) of problem behavior should be distinguished. Third, socially desirable and not necessarily honest responses could have occurred due to he fact that the present study is based on selfreport data. However, following Chan (2009) and Spector (2006) the problems with self-report data can equally occur with non-self-report data as well. Furthermore, the design of the current study predestined the use of self-report data, because: (a) students' perception were in focus, (b) internal states (i.e. anger, temper, disobedience) were explored and (c) information from adolescents are less sensitive for measurement errors in comparison to information from young children who might have more difficulties expressing their internal states. Despite these limitations the current study also has several strengths. The current statistical state of the art analyses conducted in this study is are based on a large sample of adolescent students. Hence, we simultaneously examined both relationships with peers and teachers as well as the emotional and behavioral dimension of school engagement. Overall, the findings provide an essential insight into developmental differences explaining conduct problems in middle adolescence. Thereby, BSE and ESE were identified as potential starting points for prevention and intervention strategies in school context.

\section{ACKNOWLEDGEMENT}

The research reported in this article was supported by a grant (Schumpeter Fellowship, II/84 452) from The 
Volkswagen Foundation. The authors would like to thank the principals, teachers, parents and students for their cooperation in making these studies possible.

\section{REFERENCES}

Asparouhov, T. 2005. "Sampling weights in latent variable modeling." Structural Equation Modeling 12(3):411-434. http://dx.doi.org/10.1207/s15328007sem1203 4

Bandalos, D. L. 2002. "The effects of item parceling on goodness-offit and parameter estimate bias in structural equation modeling." Structural Equation Modeling 9(1):78-102. http://dx.doi.org/10.1207/S15328007SEM0901 5

Bandalos, D. L., and Finney, S. J. 2001. "Item parceling issues in structural equation modeling." Pp. 269-296 in New developments and techniques in structural equation, edited by G. A. Marcoulides and R. E. Schumacker, Mahwah, NJ: Erlbaum.

Baron, R. M., and Kenny, D. A. 1986. "The moderator-mediator variable distinction in social psychological research: Conceptual, strategic, and statistical considerations." Journal of Personality and Social Psychology 51(6):1173-1182. http://dx.doi.org/10.1037/0022-3514.51.6.1173

Bear, G. G., Yang, C., Pell, M., and Gaskins, C. 2014. "Validation of a brief measure of teachers' perceptions of school climate: Relations to student achievement and suspensions." Learning Environments Research 17(3):339-354. http://dx.doi.org/10.1007/s10984-014-9162-1

Brand, S., Felner, R., Shim, M., Seitsinger, A., and Dumas, T. 2003. "Middle school improvement and reform: Development and validation of a school-level assessment of climate, cultural pluralism, and school safety." Journal of Educational Psychology 95(3):570-588.

http://dx.doi.org/10.1037/0022-0663.95.3.570

Bru, E., Stephens, P., and Torsheim, T. 2002. "Students' perceptions of class management and reports of their own misbehavior." Journal of School Psychology 40(4):287-307. http://dx.doi.org/10.1016/S0022-4405(02)00104-8

Caprara, G. V., Kanacri, B. P. L., Gerbino, M., Zuffianò, A., Alessandri, G., Vecchio, G., Caprara, E., Pastorelli, C., and Bridglall, B. 2014. "Positive effects of promoting prosocial behavior in early adolescence Evidence from a school-based intervention." International Journal of Behavioral Development 38(4):386-396. http://dx.doi.org/10.1177/0165025414531464

Cernkovic, S. and Giordano, P. 1979. "Delinquency, opportunity and gender." Journal of Criminal Law 70:145-151. http://dx.doi.org/10.2307/1142917

Cernkovich, S. A., and Giordano, P. C. 1992. "School bonding, race, and delinquency." Criminology 30(2):261-291. http://dx.doi.org/10.1111/j.1745-9125.1992.tb01105.x

Chan, D. 2009. "So why ask me? Are self-report data really that bad?" Pp. 309-336 in Statistical and methodological myths and urban legends: Doctrine, verity and fable in organizational and social sciences, edited by C. E. Lance and R. J. Vandenberg (Eds.), New York, NY: Routledge.

Christ, O., and Schlüter, E. 2012. Strukturgleichungsmodelle mit Mplus: eine praktische Einführung. [Structural Equation Models with Mplus: A Practical Introduction] Berlin, Germany: Walter de Gruyter. http://dx.doi.org/10.1524/9783486714807

Costello, E. J., Foley, D. L., and Angold, A. 2006. "10-year research update review: the epidemiology of child and adolescent psychiatric disorders: II. Developmental epidemiology.“ Journal of the American Academy of Child \& Adolescent Psychiatry 45(1):8-25.

http://dx.doi.org/10.1097/01.chi.0000184929.41423.c0
Danielsen, A. G., Wiium, N., Wilhelmsen, B. U., and Wold, B. 2010. "Perceived support provided by teachers and classmates and students' self-reported academic initiative." Journal of School Psychology 48(3):247-267.

http://dx.doi.org/10.1016/j.jsp.2010.02.002

Dryfoos, J. G. 1990. Adolescents at risk: Prevalence and prevention. New York, NY: Oxford University Press.

Eccles, J.S., Wigfield, A., and Schiefele, U., 1998. "Motivation to succeed." Pp. 1017-1095 in Handbook of child psychology, edited by W. Damon (Series Ed.) and N. Eisenberg (Vol. Ed.), (5th ed., Vol. III,). New York, NY: Wiley.

Eifler, S. 2002. Kriminalsoziologie [Criminological sociology]. Bielefeld, Germany: Transkript. http://dx.doi.org/10.14361/9783839400623

Estell, D. B., and Perdue, N. H. 2013. "Social support and behavioral and affective school engagement: The effects of peers, parents, and teachers." Psychology in the Schools 50(4):325339. http://dx.doi.org/10.1002/pits.21681

Fall, A., and Roberts, G. 2012. "High school dropouts: Interactions between social context, self-perceptions, school engagement, and student dropout." Journal of Adolescence 35:787-798.

http://dx.doi.org/10.1016/j.adolescence.2011.11.004

Feldman, S.S., and Elliott, G.R. 1990. At the threshold: The developing adolescent. Cambridge MA: Harvard University Press.

Finn, J. D. 1993. School Engagement and Students at Risk. Washington, DC: National Center for Education Statistics.

Finn, J. D., and Rock, D. A. 1997. "Academic success among students at risk for school failure." Journal of Applied Psychology 82:221-234. http://dx.doi.org/10.1037/0021-9010.82.2.221

Fredricks, J. A., Blumenfeld, P. C., and Paris, A. H. 2004. "School engagement: Potential of the concept, state of the evidence." Review of Educational Research 74:59-109. http://dx.doi.org/10.3102/00346543074001059

Goodman, R. 1997. "The Strengths and Difficulties Questionnaire: a research note." Journal of Child Psychology and Psychiatry 38(5):581-86.

http://dx.doi.org/10.1111/j.1469-7610.1997.tb01545.x

Gregory, A., Cornell, D., Fan, X., Sheras, P., Shih, T. H., and Huang, F. 2010. "Authoritative school discipline: High school practices associated with lower bullying and victimization." Journal of Educational Psychology 102(2):483-496. http://dx.doi.org/10.1037/a0018562

Hamre, B. K., Pianta, R. C., Downer, J. T., and Mashburn, A. J. 2008. "Teachers' perceptions of conflict with young students: Looking beyond problem behaviors." Social Development 17(1):115-136.

Harter, S. 1996. "Teacher and classmate influences on scholastic motivation, self-esteem, and level of voice in adolescents." Pp. 11-42 in Social motivation - Understanding children's school adjustment, edited by J. Juvonen and K. Wentzel, Cambridge, UK: University Press. http://dx.doi.org/10.1017/CBO9780511571190.004

Hawkins, J. D., Catalano, R. F., and Miller, J. Y. 1992. "Risk and protective factors for alcohol and other drug problems in adolescence and early adulthood: implications for substance abuse prevention." Psychological Bulletin 112(1):64-105. http://dx.doi.org/10.1037/0033-2909.112.1.64

Hirschfield PJ., and Gasper J. 2011. "The relationship between school engagement and delinquency in late childhood and early adolescence." Journal of Youth and Adolescence 40(1):3-22.

http://dx.doi.org/10.1007/s10964-010-9579-5

Hirschi, Travis. 1969. Causes of delinquency. Berkeley: University of California Press. 
Hughes, J. N., and Cavell, T. A. 1999. "Influence of the teacherstudent relationship in childhood conduct problems: A prospective study." Journal of Clinical Child Psychology 28(2):173-184.

http://dx.doi.org/10.1207/s15374424jccp2802 5

Hughes, J. N., Luo, W., Kwok, O. M., and Loyd, L. K. 2008. "Teacher-student support, effortful engagement, and achievement: A 3-year longitudinal study." Journal of Educational Psychology 100(1):1-14. http://dx.doi.org/10.1037/0022-0663.100.1.1

Jessor, R., and Jessor, S. L. 1977. Problem behavior and psychosocial development: A longitudinal study of youth. New York, NY: Academic Press

Kunter, M., Schümer, G., Artelt, C., Baumert, J., Klieme, E., Neubrand, M., Prenzel, M., Schiefele, U., Schneider, W., Stanat, P., Tillmann, K.-J. and Weiß, PISA 2000: Dokumentation der Erhebungsinstrumente [Documentation of Elicitation Instruments]. Max-Planck-Institut für Bildungsforschung.

Lamborn, S., Newmann, F., and Wehlage, G. 1992. "The significance and sources of student engagement." Student Engagement and Achievement in American Secondary Schools:11-39.

Liska, A. E., and Reed, M. D. 1985. "Ties to conventional institutions and delinquency: Estimating reciprocal effects." American Sociological Review: 547-560. http://dx.doi.org/10.2307/2095438

Little, T. D., Cunningham, W. A., Shahar, G., and Widaman, K. F. 2002. "To parcel or not to parcel: Exploring the question, weighing the merits." Structural Equation Modeling 9(2):151173. http://dx.doi.org/10.1207/S15328007SEM0902 1

Loeber, R. 1988. "Natural histories of conduct problems, delinquency, and associated substance use". Advances in clinical child psychology:73-124. New York, NY: Springer. http://dx.doi.org/10.1007/978-1-4613-9829-5 2

Loeber, R., and Dishion, T. 1983. "Early predictors of male delinquency: a review." Psychological bulletin 94(1):68-99. http://dx.doi.org/10.1037/0033-2909.94.1.68

Loukas, A., Ripperger-Suhler, K. G., and Horton, K. D. 2009. "Examining temporal associations between school connectedness and early adolescent adjustment." Journal of Youth Adolescence 38:804-812. http://dx.doi.org/10.1007/s10964-008-9312-9

MacKinnon, D. P. 2008. Introduction to statistical mediation analysis. Mahwah, NJ: Erlbaum.

Marks, H. M. 2000. "Student engagement in instructional activity: Patterns in the elementary, middle, and high school years." American Educational Research Journal 37(1):153-184. http://dx.doi.org/10.3102/00028312037001153

Marsh, H. W., Hau, K. T., Balla, J. R., and Grayson, D. 1998. "Is more ever too much? The number of indicators per factor in confirmatory factor analysis." Multivariate Behavioral Research 33(2):181-220.

http://dx.doi.org/10.1207/s15327906mbr3302 1

Marsh, H. W., Lüdtke, O., Nagengast, B., Morin, A. J., and Von Davier, M. 2013. "Why item parcels are (almost) never appropriate: Two wrongs do not make a rightCamouflaging misspecification with item parcels in CFA models." Psychological Methods 18(3):257-284. http://dx.doi.org/10.1037/a0032773

Meehan, B. T., Hughes, J. N., and Cavell, T. A. 2003. "Teacherstudent relationships as compensatory resources for aggressive children." Child Development 74(4):1145-1157. http://dx.doi.org/10.1111/1467-8624.00598

Muthén, L. K., and Muthén, B. O. 2010. 1998-2010 Mplus user's guide. Muthén and Muthén. Los Angeles, CA: Author

Murray, C., and Greenberg, M. T. 2000. "Children's relationship with teachers and bonds with school an investigation of patterns and correlates in middle childhood." Journal of School Psychology 38(5):423-445.

http://dx.doi.org/10.1016/S0022-4405(00)00034-0

Nasser, F., and Wisenbaker, J. 2003. "A Monte Carlo study investigating the impact of item parceling on measures of fit in confirmatory factor analysis." Educational and Psychological Measurement 63(5):729-757. http://dx.doi.org/10.1177/0013164403258228

Perdue, N. H., Manzeske, D. P., and Estell, D. B. 2009. "Early predictors of school engagement: Exploring the role of peer relationships." Psychology in the Schools 46(10):1084-1097. http://dx.doi.org/10.1002/pits.20446

Petermann, F., \& Petermann, U. 2013. "Störungen des Sozialverhaltens" [Conduct disorder]. Kindheit und Entwicklung 22(3):123-126. http://dx.doi.org/10.1026/0942-5403/a000108

Pintrich, P., Zusho, A., Schiefele, U., and Pekrun, R. 2001. "Goal orientation and self-regulated learning in the college classroom: A cross-cultural comparison." Pp. 149-169 in Student motivation: The culture and context of learning, edited by F. Salili, C. Y. Chiu, and Y. Y. Hong, New York, NY: Plenum. http://dx.doi.org/10.1007/978-1-4615-1273-8 8

Prats D. C. 1990. The effects of forming miniscales on the construct validity of the test anxiety inventory. Paper presented at the National Council of Measurement of Education, Boston.

Preacher, K. J., and Hayes, A. F. 2008. "Asymptotic and resampling strategies for assessing and comparing indirect effects in multiple mediator models". Behavior Research Methods 40(3):879-891. http://dx.doi.org/10.3758/BRM.40.3.879

Upadyaya, K., and Salmela-Aro, K. 2013. „Development of school engagement in association with academic success and wellbeing in varying social contexts." European Psychologist 18:136-147.

http://dx.doi.org/10.1027/1016-9040/a000143

Resnick, M. D., Bearman, P. S., Blum, R. Wm., Bauman, K. E., Harris, K. M., Jones, J., Tabor, J., Beuhring, T., Sieving, R. E., Shew, M., Ireland, M., Bearinger, L. H., Udry, J. R. 1997. "Protecting adolescents from harm: findings from the National Longitudinal Study on Adolescent Health." The Journal of the American Medical Association 278(10):823-832. http://dx.doi.org/10.1001/jama.1997.03550100049038

Roorda, D. L., Koomen, H. M. Y., Spilt, J. L., and Oort, F. J. 2011. "The influence of affective teacher-student relationships on students' school engagement and achievement: A metaanalytic approach." Review on Educational Research 81:493529. http://dx.doi.org/10.3102/0034654311421793

Shrout, P. E., and Bolger, N. 2002. "Mediation in experimental and nonexperimental studies: new procedures and recommendations." Psychological Methods 7(4):422-445. http://dx.doi.org/10.1037/1082-989X.7.4.422

Simons-Morton, B. G., Crump, A. D., Haynie, D. L., and Saylor, K. E. 1999. "Student-school bonding and adolescent problem behavior." Health Education Research 14(1):99-107. http://dx.doi.org/10.1093/her/14.1.99

Skinner, E. A., Kindermann, T. A., and Furrer, C. J. 2008. "A motivational perspective on engagement and disaffection: Conceptualization and assessment of children's behavioral and emotional participation in academic activities in the classroom." Educational and Psychological Measurement 69(3):493-525. http://dx.doi.org/10.1177/0013164408323233

Spector, P. E. 2006. "Method variance in organizational research: truth or urban legend?" Organizational Research Methods 9:221-232. http://dx.doi.org/10.1177/1094428105284955 
Steinberg, L., and Avenevoli, S. 1998. "Disengagement from school and problem behavior in adolescence: A developmentalcontextual analysis of the influences of family and part-time work." Pp. 391-424 in New Perspectives on Adolescent Risk Behavior, edited by Richard Jessor. Cambridge: Cambridge University Press.

http://dx.doi.org/10.1017/CBO9780511571138.013

Watt, H. M. 2004. 'Development of adolescents' self-perceptions, values, and task perceptions according to gender and domain in $7^{\text {th }}$-through $11^{\text {th }}$-grade Australian students." Child Development 75(5):1556-1574.

http://dx.doi.org/10.1111/j.1467-8624.2004.00757.x
Werner, E. E., and Smith, R. S. 1989. Vulnerable, but invincible. New York, NY: Adams, Bannister, Cox.

West, S. G., Finch, J. F., and Curran, P. J. 1995. Structural Equation Modeling: Concepts, Issues, and Application. Thousand Oaks, CA: Sage.

Willms, J. D. 2003. Student engagement at school: A sense of belonging and participation: Results from PISA 2000. Paris, France: Publications de l'OCDE.

Received on 18-04-2016

Accepted on 28-04-2016

Published on 25-05-2016

DOI: http://dx.doi.org/10.6000/1929-4409.2016.05.11

(C) 2016 Lätsch et al.; Licensee Lifescience Global.

This is an open access article licensed under the terms of the Creative Commons Attribution Non-Commercial License (http://creativecommons.org/licenses/by-nc/3.0/) which permits unrestricted, non-commercial use, distribution and reproduction in any medium, provided the work is properly cited. 